Research article

\title{
INFLUENCE OF EPINEPHRINE AND MEDETOMIDINE ON SYSTEMIC ABSORPTION OF LIDOCAINE APPLIED EPIDURALLY IN ANESTHETIZED SWINE
}

LIPAR Marija ${ }^{1 *}$, TURNER Rajka², RADIŠIĆ Berislav ${ }^{1}$, GRGUREVIĆ Lovorka ${ }^{3}$, ERJAVEC Igor ${ }^{3}$, BRAJENOVIĆ Nataša ${ }^{4}$, BRČIĆ KARAČONJI Irena ${ }^{4}$, SAMARDŽIJA Marko ${ }^{5}$, VNUK Dražen ${ }^{1}$

${ }^{1}$ Clinic for Surgery, Orthopedics and Ophthalmology, Faculty of Veterinary Medicine, University of Zagreb, Croatia; ${ }^{2}$ DVM, unemployed; ${ }^{3}$ Laboratory for Mineralized Tissues, Department of Anatomy, School of Medicine, University of Zagreb, Zagreb, Croatia; ${ }^{4}$ Institute for medical research and Occupational Health, Zagreb, Croatia; ${ }^{5}$ Clinic for Reproduction and Obstetrics, Faculty of Veterinary Medicine, University of Zagreb, Zagreb, Croatia

(Received 07 April; Accepted 09 September 2014)

Epinephrine and alpha 2 agonist drugs are often used with epidural anesthesia to minimize local anesthetic systemic absorption, as well as to prolong the duration of the block. The aim of the current study was to determine by which extent epinephrine and medetomidine influenced lidocaine systemic absorption rate following epidural application. This was achieved by monitoring the serum lidocaine concentration in a porcine model. During general anesthesia, the first group received epidurally plane lidocaine, the second received lidocaine containing epinephrine $(1: 80.000)$, and the third lidocaine with medetomidine $(15 \mu \mathrm{g} / \mathrm{kg})$. Venous blood samples were taken before and 5, 10, 20, 30, 45, 60 and 90 minutes following epidural administration of the anesthetic. The effects of epinephrine and medetomidine were comparable. They both failed to cause a significant decrease in serum lidocaine concentration $(p>0.05)$. In these settings we were unable to demonstrate a greater capacity of these two adrenergic agonists for reducing lidocaine systemic uptake and, accordingly, its systemic toxicity potential.

Key words: epidural, lidocaine, serum concentration, epinephrine, medetomidine, swine

\section{INTRODUCTION}

Neuraxial block is an increasingly used form of regional anesthesia designed to abolish nociception on the spinal level without the associated central nervous system (CNS) depression. In veterinary medicine epidural anesthesia is most frequently used for facilitating various diagnostic and obstetrical procedures, as well as to allow numerous surgical procedures involving the pelvic cavity, perineum and rear limbs Corresponding author: e-mail: mlipar@vef.hr 
$[1,2]$. Epidural and spinal anesthesia have been shown to decrease surgical stress response, intraoperative blood loss, and to lower the incidence of postoperative thromboembolic events along with morbidity and mortality in high risk patients $[3,4]$. When compared with general anesthesia, epidural administration of local anesthetics also results in less postoperative pulmonary complications, regardless of the risk of bronchial constriction due to sympathetic blockade [5]. In addition, the neuraxial block has been used as an adjunct to general anesthesia, for extending analgesia into the postoperative period, as well as for providing analgesia for non surgical patients without harmful side effects associated with systemic administration of opioids $[3,4,6]$. However, besides sympathetic blockade and other possible complications, the major concern with this approach remains local anesthetic systemic toxicity and its rate of absorption into the blood stream after epidural administration. Following epidural administration, in order to reach the site of action the local anesthetic needs to cross the spinal meninges [7]. It can either be taken up by the epidural fat, resorbed into the systemic circulation via venous blood vessels, or cross the dura mater and enter the cerebrospinal fluid [8]. Adrenergic agonists have been frequently combined with local anesthetics to prolong the motor - sensory block through the supposed mechanism of decreasing epidural blood flow and by causing antinociceptive effects via interaction with alpha-2-adrenoceptors located in the brain and spinal cord [9-13]. Previous studies clearly indicate that epinephrine due to its vasoconstrictive action tends to decrease local anesthetic serum peak concentration during central and peripheral block [11,14-16]. Nevertheless, studies with alpha-2-agonist drugs such as clonidine or dexmedetomidine showed less conclusive results regarding that matter $[15,17]$. Although it seems reasonable to expect that medetomidine through its agonist action on postsynaptic alpha-2-adrenoceptors could influence lidocaine systemic uptake by the same mechanism as epinephrine, at this point there are still insufficient data to support this assumption. The aim of this study was to compare by monitoring serum lidocaine concentration at 5, 10,20,30, 45, 60 and 90 minutes following epidural administration in the porcine model, to which extent epinephrine and medetomidine can influence lidocaine systemic absorption rate.

\section{MATERIALS AND METHODS}

The research was approved by the Institutional Ethics Committee and Ministry of Agriculture, Republic of Croatia. Sixteen healthy piglets of mixed Landras breed aged two to four months of both genders were housed at the Clinic for Surgery, Orthopedics and Ophthalmology at the Faculty of Veterinary Medicine University of Zagreb in standard microclimatic conditions. All animals were considered healthy on the basis of clinical examination which comprised body temperature (rectal thermometer) and heart and respiration rate measurements (chest auscultation). The animals were fasted for 12 hours, and water was withheld 4 hours prior to the experiment. 
The animals were randomly divided into three groups according to the epidurally applied anesthetic mixture; group one $(\mathrm{L} ; \mathrm{n}=5)$ received epidurally plain $2 \%$ lidocaine $\left(\right.$ Lidokain $^{\circledR}$, Belupo, Croatia) in a dose of $1 \mathrm{ml} / 5 \mathrm{~kg}$. Group two (LE; $\mathrm{n}=5$ ) received $2 \%$ lidocaine with $12.5 \mu \mathrm{g} / \mathrm{ml}$ (1: 80.000) of epinephrine (Lidokain-adrenalin ${ }^{\circledR}$, Belupo, Croatia) in a dose of $1 \mathrm{ml} / 5 \mathrm{~kg}$, and group three $(\mathrm{LM} ; \mathrm{n}=6)$ received $2 \%$ lidocaine with $15 \mu \mathrm{g} / \mathrm{kg}$ of medetomidine (Domitor ${ }^{\circledR}$, Pfizer, Finland) $1 \mathrm{ml} / 5 \mathrm{~kg}$.

The animals were premedicated with $0.1 \mathrm{mg} / \mathrm{kg}$ of intramuscularly administered (IM) acepromazine (PromAce ${ }^{\circledR}$ Injectable, Fort Dodge, USA) and $5 \mathrm{mg} / \mathrm{kg}$ IM of ketamine $\left(\right.$ Narketan $^{\circledR} 10$, Vetoquinol, Switzerland). Thirty minutes following premedication an intravenous catheter was placed in the $v$. auricularis. During the whole procedure the animals received $0.9 \%$ sodium chloride solution i.v. in a dose of $10 \mathrm{ml} / \mathrm{kg} / \mathrm{h}$. General anesthesia was used to minimize suffering during arterial blood sampling and to facilitate the epidural administration of drugs by avoiding potentially dangerous rapid movements of the animals. Anesthesia was induced with intravenously applied sodium thiopental (Nesdonal ${ }^{\circledR}$, Abbott Laboratories, USA) in a dose of $5 \mathrm{mg} / \mathrm{kg}$. Following endotracheal intubation, anesthesia was maintained with isoflurane (Forane ${ }^{\circledR}$, Abbott Laboratories, USA) in 100\% oxygen. The vaporizer was set at 3\% during the first five minutes, after which anesthesia was maintained with $1.5 \%$ isoflurane. During anesthesia the vital functions of the animals were monitored including $\mathrm{SpO}_{2}, \mathrm{ECG}$, invasive arterial blood pressure and $\mathrm{EtCO}_{2}$ (Datex Ohmeda, USA).

Epidural anesthesia was applied 20 minutes following induction. Animals were placed in sternal recumbency, and the skin was aseptically prepared prior to the epidural application of the anesthetic. The epidural needle was introduced between L7-S1 by using the "loss of resistance" technique to identify the epidural space. Instead of performing the epinephrine test dose, epidural drug administration was preceded by syringe aspiration in order to eliminate the possibility of intravascular injection or puncture of the dura. In the case that blood or cerebrospinal fluid was aspirated, epidural anesthesia would be discontinued and the animal excluded from the experiment.

Venous blood samples were obtained from the cephalic vein and stored into sterile test tubes (BD vacutainer SST, $4 \mathrm{ml}$, Plymouth, UK). In all three groups, blood samples were taken prior to epidural anesthesia and 5, 10, 20, 30, 45, 60 and 90 minutes following epidural administration of the anesthetic. Blood samples were centrifuged at 15,800 revolutions per minute (RPM) for 90 seconds, and $1 \mathrm{ml}$ of blood serum was stored into a sterile plastic cuvette at $-70{ }^{\circ} \mathrm{C}$ pending analysis. Serum lidocaine concentration was measured using gas chromatography mass spectrophotometry (Varian 3400 CXSaturn 4D, USA) [18].

Statistical analysis was performed by using STATISTICA, version 6.1. (StatSoft, USA). Serum lidocaine concentration was evaluated using multiple regression analysis with peak serum lidocaine concentration as the dependent variable, while the combination of medetomidine and epinephrine with lidocaine and serum lidocaine concentration 
measured in the described time intervals were the independent variables. Variance analysis and Duncan test were used for the evaluation of the results pertaining to hemodynamic parameters. The level of significance was set at $\mathrm{P}=0.05$ and the results were expressed as mean values $\pm \mathrm{SD}$.

\section{RESULTS}

Average body weight of animals in the L group was $38.2 \pm 13.2 \mathrm{~kg}$, LE group $28.6 \pm$ $2.2 \mathrm{~kg}$ and LM group $34.8 \pm 10.3 \mathrm{~kg}$.

Serum lidocaine concentrations are displayed in Table 1.

Table 1. Serum lidocaine concentration $(\mu \mathrm{g} / \mathrm{ml})$ measured in all three groups of animals (L-lidocaine group, LM - lidocaine + medetomidine group, LE - lidocaine + epinephrine group). Data are presented as mean $\pm \mathrm{SD}$

\begin{tabular}{|c|c|c|c|c|c|c|c|c|c|}
\hline & $\begin{array}{l}\text { Time } \\
(\mathrm{min})\end{array}$ & 0 & 5 & 10 & 20 & 30 & 45 & 60 & 90 \\
\hline & Group & & & & & & & & \\
\hline Lidocaine & LE & $0 \pm 0$ & $\begin{array}{c}1.64 \pm \\
1.76\end{array}$ & $\begin{array}{c}0.93 \pm \\
0.31\end{array}$ & $\begin{array}{c}0.86 \pm \\
0.10\end{array}$ & $\begin{array}{c}0.90 \pm \\
0.21\end{array}$ & $\begin{array}{c}0.78 \pm \\
0.19\end{array}$ & $\begin{array}{c}0.71 \pm \\
0.26\end{array}$ & $\begin{array}{c}0.68 \pm \\
0.21\end{array}$ \\
\hline concentration & $\mathrm{LM}$ & $0 \pm 0$ & $\begin{array}{c}1.38 \pm \\
0.70\end{array}$ & $\begin{array}{c}1.26 \pm \\
0.43\end{array}$ & $\begin{array}{c}0.98 \pm \\
0.27\end{array}$ & $\begin{array}{c}0.87 \pm \\
0.23\end{array}$ & $\begin{array}{c}0.78 \pm \\
0.23\end{array}$ & $\begin{array}{c}0.71 \pm \\
0.14\end{array}$ & $\begin{array}{c}0.56 \pm \\
0.13\end{array}$ \\
\hline$(\mu \mathrm{g} / \mathrm{ml})$ & $\mathrm{L}$ & $0 \pm 0$ & $\begin{array}{c}1.10 \pm \\
0.58\end{array}$ & $\begin{array}{c}1.10 \pm \\
0.46\end{array}$ & $\begin{array}{c}1.21 \pm \\
0.42\end{array}$ & $\begin{array}{c}1.04 \pm \\
0.31\end{array}$ & $\begin{array}{c}1.03 \pm \\
0.37\end{array}$ & $\begin{array}{c}0.95 \pm \\
0.38\end{array}$ & $\begin{array}{c}0.74 \pm \\
0.27\end{array}$ \\
\hline
\end{tabular}

The maximum peak serum lidocaine concentration $\left(\mathrm{C}_{\max }\right)$ in $\mathrm{LE}(1.64 \pm 1.6 \mu \mathrm{g} / \mathrm{ml})$ and LM $(1.38 \pm 0.70 \mu \mathrm{g} / \mathrm{ml})$ group was recorded five minutes following administration. $\mathrm{C}_{\max }$ value in the $\mathrm{L}$ group was recorded in the twentieth minute $(1.21 \pm 0.42 \mu \mathrm{g} / \mathrm{ml})$. Ten minutes following administration serum lidocaine concentration in LE group decreased to $0.93 \pm 0.31 \mu \mathrm{g} / \mathrm{ml}$, but the difference was not statistically significant when compared to the serum lidocaine concentration measured in L group (1.10 \pm $0.46 \mu \mathrm{g} / \mathrm{ml} ; \mathrm{p}>0.05)$. In LM group a slight decline in serum lidocaine concentration was recorded in the twentieth minute $(0.98 \pm 0.27 \mu \mathrm{g} / \mathrm{ml})$, while 30 minutes following administration serum lidocaine concentration measured in LM group (0.87 \pm $0.23 \mu \mathrm{g} / \mathrm{ml})$ was very close to the value measured in LE group $(0.90 \pm 0.21 \mu \mathrm{g} / \mathrm{ml})$. Both recorded values were statistically insignificant in comparison to the value measured in L group $(1.04 \pm 0.31 \mu \mathrm{g} / \mathrm{ml})$. The lowest serum lidocaine concentration was recorded 90 minutes following administration in LM group $(0.56 \pm 0.13 \mu \mathrm{g} / \mathrm{ml})$.

Hemodynamic parameters are shown in Table 2. Mean arterial pressure values recorded in LE group were significantly lower than those measured in L and LM group ( $\mathrm{p} \leq$ 0.05). The highest mean arterial pressure was recorded in the LM group during the first 20 minutes following epidural application. Correspondingly, systolic and diastolic pressure was significantly lower in LE group when compared to the remaining two groups $(\mathrm{p} \leq 0.05)$. In the LE group the recorded heart rate values were significantly 
higher than those recorded in L and LM group between the tenth and fortieth minute of the experiment (Table 2).

Table 2. Hemodynamic parameters measured in all three groups of animals ( $\mathrm{L}$-lidocaine group, LM -lidocaine + medetomidine group, LE -lidocaine + epinephrine group)

\begin{tabular}{|c|c|c|c|c|c|}
\hline $\begin{array}{l}\text { Time } \\
\text { (min) }\end{array}$ & Group & $\begin{array}{l}\text { Systolic } \\
\text { pressure } \\
(\mathrm{mmHg})\end{array}$ & $\begin{array}{l}\text { Diastolic } \\
\text { pressure } \\
(\mathrm{mmHg})\end{array}$ & $\begin{array}{c}\text { Mean arterial } \\
\text { pressure } \\
(\mathrm{mmHg})\end{array}$ & $\begin{array}{l}\text { Heart rate } \\
\text { (bpm) }\end{array}$ \\
\hline \multirow{3}{*}{0} & LE & $97.80 \pm 17.57$ & $59.00 \pm 15.23$ & $72.40 \pm 13.43$ & $163.22 \pm 59.43$ \\
\hline & LM & $115.60 \pm 14.93$ & $61.40 \pm 20.91$ & $82.20 \pm 20.63$ & $153.40 \pm 42.97$ \\
\hline & $\mathrm{L}$ & $135.50 \pm 32.98$ & $76.00 \pm 20.48$ & $101.67 \pm 25.29$ & $116.67 \pm 24.28$ \\
\hline \multirow{3}{*}{2} & LE & $98.67 \pm 10.50^{\mathrm{a}}$ & $47.00 \pm 2.00^{\mathrm{a}}$ & $65.00 \pm 4.00^{\mathrm{a}}$ & $158.82 \pm 54.72$ \\
\hline & LM & $134.80 \pm 12.64^{\mathrm{b}}$ & $91.20 \pm 14.89^{\mathrm{b}}$ & $108.40 \pm 12.92^{\mathrm{b}}$ & $149.20 \pm 34.63$ \\
\hline & $\mathrm{L}$ & $122.33 \pm 20.60^{\text {a.b }}$ & $70.33 \pm 12.58^{\mathrm{b}}$ & $90.67 \pm 15.04^{\mathrm{b}}$ & $115.35 \pm 21.08$ \\
\hline \multirow{3}{*}{5} & $\mathrm{LE}$ & $86.25 \pm 11.32^{\mathrm{a}}$ & $46.00 \pm 3.56^{\mathrm{a}}$ & $61.50 \pm 3.00^{\mathrm{a}}$ & $178.60 \pm 64.16$ \\
\hline & $\mathrm{LM}$ & $137.20 \pm 11.61^{\mathrm{b}}$ & $94.42 \pm 11.69^{\mathrm{b}}$ & $111.20 \pm 10.71^{\mathrm{b}}$ & $137.20 \pm 21.99$ \\
\hline & $\mathrm{L}$ & $119.67 \pm 29.28^{\mathrm{b}}$ & $65.00 \pm 12.12^{\mathrm{c}}$ & $86.00 \pm 16.52^{\mathrm{c}}$ & $115.80 \pm 20.54$ \\
\hline \multirow{3}{*}{10} & $\mathrm{LE}$ & $85.60 \pm 11.15^{\mathrm{a}}$ & $51.40 \pm 8.96^{\mathrm{a}}$ & $62.33 \pm 4.73^{\mathrm{a}}$ & $182.20 \pm 61.18^{\mathrm{a}}$ \\
\hline & $\mathrm{LM}$ & $134.00 \pm 12.63^{\mathrm{b}}$ & $89.80 \pm 16.35^{\mathrm{b}}$ & $106.80 \pm 15.55^{\mathrm{b}}$ & $144.60 \pm 31.45^{\mathrm{a} . \mathrm{b}}$ \\
\hline & $\mathrm{L}$ & $123.00 \pm 27.22^{\mathrm{b}}$ & $64.33 \pm 12.74^{\mathrm{a}}$ & $83.33 \pm 18.01^{\text {a.b }}$ & $107.55 \pm 14.25^{\mathrm{b}}$ \\
\hline \multirow{3}{*}{15} & LE & $85.25 \pm 14.93^{\mathrm{a}}$ & $49.75 \pm 6.70^{\mathrm{a}}$ & $62.75 \pm 4.99^{\mathrm{a}}$ & $177.60 \pm 64.74^{a}$ \\
\hline & LM & $133.00 \pm 12.81^{\mathrm{b}}$ & $86.20 \pm 15.67^{\mathrm{b}}$ & $104.20 \pm 14.65^{\mathrm{b}}$ & $141.00 \pm 17.71^{\text {a.b }}$ \\
\hline & $\mathrm{L}$ & $123.67 \pm 24.42^{\mathrm{b}}$ & $64.67 \pm 13.28^{\mathrm{a}}$ & $85.33 \pm 17.04^{\mathrm{b}}$ & $108.37 \pm 17.76^{b}$ \\
\hline \multirow{3}{*}{20} & LE & $83.40 \pm 13.94^{\mathrm{a}}$ & $43.00 \pm 11.47^{\mathrm{a}}$ & $58.20 \pm 8.11^{a}$ & $178.20 \pm 49.67^{\mathrm{a}}$ \\
\hline & $\mathrm{LM}$ & $122.60 \pm 12.72^{\mathrm{b}}$ & $71.40 \pm 13.76^{\mathrm{b}}$ & $95.60 \pm 10.90^{\mathrm{b}}$ & $132.02 \pm 15.42^{\mathrm{b}}$ \\
\hline & $\mathrm{L}$ & $121.37 \pm 25.29^{\mathrm{b}}$ & $65.00 \pm 17.35^{\mathrm{b}}$ & $84.00 \pm 21.66^{\mathrm{b}}$ & $105.20 \pm 17.91^{\mathrm{b}}$ \\
\hline \multirow{3}{*}{30} & $\mathrm{LE}$ & $83.40 \pm 3.21^{\mathrm{a}}$ & $46.40 \pm 10.26^{a}$ & $58.40 \pm 8.20^{\mathrm{a}}$ & $171.02 \pm 61.99^{\mathrm{a}}$ \\
\hline & LM & $112.00 \pm 18.64^{\mathrm{b}}$ & $69.60 \pm 11.28^{b}$ & $80.60 \pm 14.10^{\mathrm{b}}$ & $128.82 \pm 14.64^{\text {a.b }}$ \\
\hline & $\mathrm{L}$ & $125.00 \pm 22.61^{\mathrm{b}}$ & $65.00 \pm 12.17^{\mathrm{b}}$ & $84.33 \pm 17.62^{\mathrm{b}}$ & $103.70 \pm 17.40^{\mathrm{b}}$ \\
\hline \multirow{3}{*}{40} & LE & $88.20 \pm 6.22$ & $42.00 \pm 8.92^{\mathrm{a}}$ & $59.60 \pm 6.43^{a}$ & $167.40 \pm 53.17^{\mathrm{a}}$ \\
\hline & LM & $109.00 \pm 14.32$ & $68.80 \pm 9.98^{\mathrm{b}}$ & $83.60 \pm 8.79^{\mathrm{b}}$ & $130.60 \pm 13.69^{a . b}$ \\
\hline & $\mathrm{L}$ & $94.00 \pm 39.15$ & $80.67 \pm 23.67^{\mathrm{b}}$ & $100.00 \pm 24.04^{\mathrm{b}}$ & $100.68 \pm 18.59^{\mathrm{b}}$ \\
\hline \multirow{3}{*}{50} & LE & $82.60 \pm 10.01^{\mathrm{a}}$ & $43.00 \pm 9.67^{\mathrm{a}}$ & $60.00 \pm 4.47^{\mathrm{a}}$ & $144.24 \pm 47.28$ \\
\hline & LM & $112.80 \pm 20.39^{a . b}$ & $65.00 \pm 20.36^{\mathrm{b}}$ & $81.20 \pm 19.54^{\mathrm{b}}$ & $112.84 \pm 11.80$ \\
\hline & $\mathrm{L}$ & $124.00 \pm 39.60^{\mathrm{b}}$ & $65.00 \pm 22.63^{\mathrm{b}}$ & $87.00 \pm 28.28^{\mathrm{b}}$ & $99.68 \pm 20.28$ \\
\hline \multirow{3}{*}{60} & LE & $79.00 \pm 13.47^{\mathrm{a}}$ & $44.40 \pm 10.06^{\mathrm{a}}$ & $58.20 \pm 3.11^{\mathrm{a}}$ & $155.84 \pm 60.88$ \\
\hline & LM & $112.50 \pm 15.29^{\mathrm{a} . \mathrm{b}}$ & $69.75 \pm 8.02^{\mathrm{b}}$ & $83.25 \pm 10.05^{\mathrm{b}}$ & $115.75 \pm 23.31$ \\
\hline & $\mathrm{L}$ & $126.55 \pm 35.99^{\mathrm{b}}$ & $67.50 \pm 21.92^{\mathrm{b}}$ & $89.50 \pm 27.58^{\mathrm{b}}$ & $101.83 \pm 21.15$ \\
\hline \multirow{3}{*}{75} & LE & $85.00 \pm 9.85^{\mathrm{a}}$ & $41.80 \pm 8.04^{\mathrm{a}}$ & $59.00 \pm 2.55^{\mathrm{a}}$ & $161.62 \pm 64.86$ \\
\hline & LM & $106.62 \pm 14.79^{a . b}$ & $57.80 \pm 12.81^{\mathrm{a} . \mathrm{b}}$ & $73.80 \pm 11.14^{\text {a.b }}$ & $122.80 \pm 29.35$ \\
\hline & $\mathrm{L}$ & $124.05 \pm 32.46^{\mathrm{b}}$ & $82.50 \pm 40.31^{\mathrm{b}}$ & $96.50 \pm 36.06^{\mathrm{b}}$ & $101.35 \pm 21.03$ \\
\hline \multirow{3}{*}{90} & LE & $89.22 \pm 9.50^{\mathrm{a}}$ & $46.80 \pm 5.26^{a}$ & $59.80 \pm 6.50^{\mathrm{a}}$ & $162.64 \pm 68.98$ \\
\hline & LM & $121.60 \pm 12.64^{b}$ & $69.60 \pm 14.24^{\mathrm{b}}$ & $87.82 \pm 14.33^{\mathrm{b}}$ & $125.02 \pm 40.27$ \\
\hline & $\mathrm{L}$ & $108.50 \pm 3.54^{\mathrm{b}}$ & $54.00 \pm 0.00^{\mathrm{a} . \mathrm{b}}$ & $74.50 \pm 3.54^{\text {a.b }}$ & $97.87 \pm 15.55$ \\
\hline
\end{tabular}

Data are presented as mean \pm SD

${ }^{\mathrm{a}}$ - significantly different from group L; ${ }^{\mathrm{b}}$ - significantly different from group LM ( $\left.\mathrm{p} \leq 0.05\right)$ 


\section{DISCUSSION}

Results of the current study showed that epinephrine and medetomidine within different time frames both influenced lidocaine systemic absorption rate almost to the same extent, but the decrease in serum lidocaine peak concentration was not statistically significant. In previous studies epinephrine has been shown, not only to decrease local anesthetic systemic absorption rate, but also to prolong duration and improve quality of the epidural block when applied in combination with the moderately potent lidocaine, as well as with more dilute solutions of potent local anesthetics like bupivacaine or ropivacaine $[11,16,19,20]$. On the contrary, the most likely reason why the same results were not recorded when epinephrine was added to concentrated solutions of bupivacaine and ropivacaine is that duration of action of these agents exceeds the duration of epinephrine's effects [16]. Furthermore, prolonged duration and improved quality of the epidural block can be at least in one part explained by epinephrine's ability to induce analgesia through the interaction with alpha-2-adrenergic receptors located in the brain and spinal cord [9-11,13]. Mazoit et al. [15] managed to significantly decrease serum lidocaine peak concentration in orthopedic patients using epinephrine in a concentration of $1: 200.000$ and clonidine (300 $\mu \mathrm{g} / 2 \mathrm{ml})$ with epidurally administered lidocaine $(20 \mathrm{ml}$ of $2 \%$ solution). Both agents caused a significant decrease in serum lidocaine concentration, and possible explanation for this result lies within the relatively high dose of clonidine used in this case, which suppressed its central antihypertensive effect mediated by its action of decreasing central sympathetic outflow $[3,6,15]$. When used in smaller doses (5 to $10 \mu \mathrm{g} /$ $\mathrm{ml})$, clonidine seems to promote lidocaine systemic absorption rather than decreasing it [17]. In contrast to partially selective clonidine (alpha-2 to alpha-1 selectivity ratio 220), medetomidine is 7 times more selective for alpha-2-receptors, with alpha-2 to alpha-1 selectivity ratio of 1620 [21,22]. Medetomidine has less agonist action on presynaptic alpha-2-adrenoceptors when compared to clonidine, and can produce pronounced transient vasoconstriction due to its interaction with postsynaptic alpha2-adrenoceptors, while in the later course of action usually induces sympatholysis and hypotension [23-25]. According to expectations, in our study medetomidine began to act in 20 minutes following administration, and showed its vasoconstrictive potency within the epidural space to be virtually the same as that of epinephrine. In the thirtieth minute, the measured value of serum lidocaine concentration in LE group was $0.90 \pm 0.21 \mu \mathrm{g} / \mathrm{ml}$, which was very close to the value measured in $\mathrm{LM}$ group $(0.87 \pm 0.23 \mu \mathrm{g} / \mathrm{ml})$. The same trend continued through the whole experiment, suggesting that medetomidine in a dose of $15 \mu \mathrm{g} / \mathrm{kg}$, though acting with a certain delay, has effects comparable to those of epinephrine. Brose and Cohen [9] used several concentrations of epinephrine $(1: 400.000,1: 300.000$ and $1: 200.000$, respectively) with $2 \%$ lidocaine in pregnant women scheduled for cesarean section, and were unable to demonstrate significant differences in either maternal or fetal serum lidocaine levels between patients given plain and epinephrine containing lidocaine solution. The authors suggested that enhanced epidural blood flow caused by inferior vena cava 
compression along with decreased vascular reactivity to catecholamines commonly observed during pregnancy might have been the key factor which led to epinephrine's loss of vasoconstrictive potency within the epidural space.

It has been suggested that a reduction in local anesthetic peak serum concentration may be a result of epinephrine's effect on systemic circulation [4]. Sharrock et al. [26] demonstrated that intravenous administration of a low epinephrine dose significantly influences local anesthetic serum concentration following epidural application. Arterial blood concentrations of bupivacaine were found to be significantly lower in patients receiving epinephrine infusions in comparison to those receiving phenylephrine. As this outcome was evidently not a result of local anesthetic reduced clearance from the injection site, the assumption was made that epinephrine mediated an increase in cardiac output which probably caused its greater volume of distribution, which in turn led to decreased blood concentration of bupivacaine. The fact that the same result was not recorded in patients given phenylephrine further indorses the theory because, unlike low epinephrine doses, phenylephrine induces increased systemic blood pressure which results in reflex bradycardia and a transient decrease in cardiac output [27]. The same effect was observed in our study, where epinephrine following absorption from the epidural space also induced a significant arterial pressure drop followed by compensatory tachycardia (Table 2). Vnuk et al. [1] also recorded similar hemodynamic values, as well as increased cardiac output in dogs epidurally receiving lidocaine -epinephrine mixture in comparison to those receiving lidocaine alone.

Considering that relatively high concentrations of epinephrine and medetomidine used in this study, we can only speculate why a significant decrease in serum lidocaine concentration failed to occur. Inadequate dosing of epinephrine and medetomidine can hardly be accounted for this result, because epinephrine concentration was 2.4 times higher than those usually employed for epidural anesthesia, and medetomidine in the used dose had an effect very similar to that of epinephrine. Epinephrine concentrations of $1: 200.000$ or even lower have been proven effective in decreasing local anesthetic serum peak concentration [14], and yet in our case, the same result was not observed. Although relatively high, the epinephrine dose was still in the so called "therapeutic range", which was measurable by its agonist action on beta-2-adrenoceptors in the muscle vasculature, leading to a reduction in systemic vascular resistance and cardiac output increase. Even though otherwise shown to decrease local anesthetic peak serum concentration through increasing its volume of distribution [26,28], in our case the increase in cardiac output did not result in the expected outcome.

Nevertheless, it needs to be pointed out that our study differs substantially from the ones listed above, because all of the animals were anesthetized and none of them were exposed to surgical stimulation which through sympathetic activity normally provides a counterbalance to the depressant action of general anesthetics on the vasomotor function [26]. On the other hand, to assume that general anesthesia played a part in opposing epinephrine's action at the injection site does not seem very reasonable, hence the recorded hemodynamic parameters clearly indicate that epinephrine was 
more than abundant in the systemic circulation (Table 2). This eliminates the only remaining plausible explanation for these results, hence there were no other known elements such as increased intraabdominal pressure that would oppose adrenergic agonists' action at the injection site.

Interestingly, medetomidine caused an increased systemic vascular resistance during the first twenty minutes following administration, while it seems to have preserved its action on postsynaptic alpha-2-adrenoceptors in the vasculature within the epidural space during the entire experiment. Nonetheless, alpha-2-adrenoceptor agonists are usually given with a different purpose, so further increasing the medetomidine dose to accomplish the epinephrine - like effect within the epidural space may not be advisable because of its undesirable effects on systemic circulation.

\section{CONCLUSION}

Results of the current study indicate that both epidurally applied adrenergic agonists in the stated dosages do not significantly influence the lidocaine systemic absorption rate. Therefore, a potential benefit from their action in reducing lidocaine systemic toxicity seems limited.

\section{Acknowledgements}

This study was fundend by Ministry of Science, Republic of Croatia.

\section{REFERENCES}

1. Vnuk D, Nesek-Adam V, Pecin M, Musulin A, Lemo N, Brajenovic N, Brcic Karaconji I, Radisic B, Smolec O, Lipar M: Hemodynamic effects of epidural lidocaine vs lidocaine adrenaline in dogs. Vet arhiv 2011, 81: 585-595.

2. Habibian S, Bigham AS, Aali E: Comparison of lidocaine, tramadol and lidocaine-tramadol for epidural analgesia in lambs. Res Vet Sci 2011, 3: 434-438.

3. Jones RS: Epidural analgesia in the dog and cat. Vet J 2001, 161: 123-131.

4. Bernards CM, Kopacz DJ: Effect of adrenaline on lidocaine clearance in vivo. Anesthesiology 1999, 91: 962-968.

5. Groeben H: Epidural anesthesia and pulmonary function. J Anesth 2006, 20: 290-299.

6. Lubenow TR, Ivankovich AD, Barkin RL: Management of acute postoperative pain. In: Barash PG, Cullen BF, Stoelting RK (Eds.). Clinical Anesthesia. Lippincott Williams \& Wilkins, Philadelphia, USA, IV edition 2002, 1405-1437.

7. Clement R, Malinowsky J-M, Le Corre P, Dollo G, Chevanne F, Le Verge R: Cerebrospinal fluid bioavailability and pharmacokinetics of bupivacaine and lidocaine after intrathecal and epidural administration in rabbits using microdialysis. J Pharmacol Exp Ther 1999, 289: 1015-1021.

8. Jamous MA, Hand CW, Moore RA, Teddy PJ, McQuay HJ: Epinephrine reduces systemic absorption of extradural diacetylmorphine. Anesthesia \& Analgesia 1986, 65: 1290-1294. 
9. Brose WG, Cohen SE: Epidural lidocaine for cesarean section: effect of varying epinephrine concentration. Anesthesiology 1988, 69: 936-940.

10. Curatolo M, Petersen-Felix S, Arendt-Nielsen, L, Zbinden AM: Epidural epinephrine and clonidine: segmental analgesia and effects on different pain modalities. Anesthesiology 1997, 87: 785-794.

11. Niemi G, Breivik H: Epinephrine markedly improves thoracic epidural analgesia produced by a small -dose infusion of ropivacaine, fentanyl, and epinephrine after major thoracic or abdominal surgery: a randomized, double -blinded crossover study with and without epinephrine. Anesthesia \& Analgesia 2002, 94: 1598-1605.

12. Singh V, Amarpal, Kinjavdekar P, Aithal HP, Pratap K: Medetomidine with ketamine and bupivacaine for epidural analgesia in buffaloes. Vet Res Comm 2005, 29: 1-18.

13. Liu SS, Lin Y: Local anesthetics. In: Clinical Anesthesia. Barash PG, Cullen BF, Stoelting RK, Cahalan MK, Stock CM (Eds.). Lippincott Williams \& Wilkins, Philadelphia, USA, VI edition 2009, 531-547.

14. Ohno H, Watanabe M, Saitoh J, Saegusa Y, Hasegawa Y, Yonezawa T: Effect of epinephrine concentration on lidocaine disposition during epidural anesthesia. Anesthesiology 1988, 68: 625-628.

15. Mazoit JX, Benhamou D, Veillette Y, Samii K: Clonidine and or adrenaline decrease lignocaine plasma peak concentration after epidural injection. Br J Clin Pharmacol 1996, 42: 242-245.

16. Bernards C: Epidural and spinal anesthesia. In: Clinical Anesthesia. Barash PG, Cullen BF, Stoelting RK, Cahalan MK, Stock CM (Eds.). Lippincott Williams \& Wilkins, Philadelphia, USA, VI edition 2009, 927-954.

17. Nishikawa T, Dohi S: Clinical evaluation of clonidine added to lidocaine solution for epidural anesthesia. Anesthesiology 1990, 73: 853-859.

18. Ohshima T, Takayasu T: Simultaneous determination of local anesthetics including estertype anesthetics in human plasma and urine by gas chromatography-mass spectrometry with solid-phase extraction. J Chromatogr B Biomed Sci Appl 1999, 726: 185-194.

19. Rostami M, Vesal N: The effects of adding epinephrine or xylazine to lidocaine solution for lumbosacral epidural analgesia in fat-tailed sheep. JSAVA 2012 http://dx.doi.org/10.4102/ jsava.v83i1.1.

20. Durej M, Ledecký V, Michalák D, Hluchý M, Kòazovický D: Efficacy of epidural administration of morphine with bupivacaine for orthopaedic surgery in sheep. Acta Vet (Beograd) 2012, 62: 111-119.

21. Johnson JO, Grecu L, Lawson NW: Autonomic nervous system. In: Clinical Anesthesia. Barash PG, Cullen BF, Stoelting RK, Cahalan MK, Stock CM (Eds.). Lippincott Williams \& Wilkins, Philadelphia, USA, VI edition 2009, 326-368.

22. Virtanen R, Savola JM, Saano V, Nyman L: Characterization of the selectivity, specificity and potency medetomidine as an alpha 2-adrenoceptor agonist. Eur J Pharm 1988, 150; 9-14.

23. Hall LW, Clarke KW: Veterinary Anaesthesia. WB Saunders, London, UK, IX edition 1991, 58-63.

24. Hellyer PW, Robertson SA, Fails AD: Pain and its management. In: Lumb \& Jones' veterinary anesthesia and analgesia. Tranquilli WJ, Thurmon JC, Grimm KA (Eds.). Blackwell Publishing, Iowa, USA, V edition 2007, 31-57. 
25. Lemke KA: Anticholinergics and sedatives. In: Lumb \& Jones' veterinary anesthesia and analgesia. Tranquilli WJ, Thurmon JC, Grimm KA (Eds.). Blackwell Publishing, Iowa, USA, V edition 2007, 203-239.

26. Sharrock NE, Go G, Mineo R: Effect of i.v. low -dose adrenaline and phenylephrine infusions on plasma concentrations of bupivacaine after lumbar extradural anesthesia in elderly patients. Br J Anesth 1991, 67: 694-698.

27. Saikh MI: Autonomic nervous system. In: Basics of anesthesia. Stoelting RK, Miller RD (Eds.). Elsevier Churchill Livingstone, Philadelphia, USA, V edition 2007, 64-76.

28. Salevsky FC, Whalley DG, Kalant D, Crawhall J: Epidural epinephrine and the systemic circulation during peripheral vascular surgery. Can J Anesth 1990, 37: 160-165.

\section{UTICAJ EPINEFRINA I MEDETOMIDINA NA SISTEMSKU RESORPCIJU EPIDURALNO PRIMENJENOG LIDOKAINA KOD ANESTEZIRANIH SVINJA}

LIPAR Marija, TURNER Rajka, RADIŠIĆ Berislav, GRGUREVIĆ Lovorka, ERJAVEC Igor, BRAJENOVIĆ Nataša, BRČIĆ KARAČONJI Irena, SAMARDŽIJA Marko, VNUK Dražen

Epinefrin i alfa 2 agonisti se uvek koriste u epiduralnoj anesteziji da umanje sistemsku apsorpciju lokalnog anestetika i da produže trajanje epiduralnog bloka. U serumu svinja se određivala koncentracija lidokaina, stoga je cilj ove studije da se odredi do koje mere epinefrin i medetomidin utiču na sistemsku apsorpciju lidokaina nakon epiduralne primene. Tokom opšte anestezije prvoj grupi je epiduralno aplikovan lidokain, drugoj lidokain s epinefrinom (1: 80000), a trećoj lidokain sa medetomidinom (15 $\mu \mathrm{g} /$ $\mathrm{kg})$. Krv iz vene je uzorkovana pre, 5, 10, 20, 30, 45, 60 i 90 minuta nakon epiduralne primene anestetika. Poređeni su efekti epinefrina i medetomidina, ali ni jedan nije signifikantno smanjio serumsku koncentraciju lidokaina $(\mathrm{p}>0,05)$. Ove kombinacije adrenergičnih agonista nisu smanjile sistemsku resorpciju lidokaina. U skladu s tim, potencijalno je moguća sistemska toksičnost lidokaina. 